\title{
Overdenture dengan Pegangan Telescopic Crown
}

\author{
Pambudi Santoso T, Heriyanti Amalia K, dan M.Th. Esti Tjahjanti \\ Program Studi Prostodonsia, PPDGS, Fakultas Kedokteran Gigi, Universitas Gadjah Mada \\ JI Denta No 1 Sekip Utara, Yogyakarta, Indonesia; e-mail: pambudi.santoso@gmail.com
}

\begin{abstract}
ABSTRAK
Kaitan presisi merupakan alat retensi mekanis yang menghubungkan antara satu atau lebih pegangan gigi tiruan, yang bertujuan untuk menambah retensi dan/atau stabilisasi. Kaitan presisi dapat digunakan secara luas pada gigi tiruan cekat, gigi tiruan sebagian lepasan, overdenture, implant untuk retensi overdenture, dan protesa maksilo fasial. Overdenture dengan kaitan presisi dapat membantu dalam pembagian beban kunyah, meminimalkan trauma pada gigi pegangan dan jaringan lunak, meminimalkan resorbsi tulang, dan meningkatkan estetik dan pengucapan suara. Salah satu jenis dari kaitan presisi adalah telescopic crown, terdiri dari 2 macam mahkota, yaitu mahkota primer yang melekat secara permanen pada gigi penyangga, dan mahkota sekunder yang melekat pada gigi tiruan. Tujuan pemaparan kasus ini adalah untuk memberikan informasi tentang rehabilitasi pasien edentulous sebagian rahang atas dengan telescopic crown.. Pasien wanita berusia 45 tahun datang ke klinik prostodonsia RSGM Prof.Soedomo dengan keluhan ingin dibuatkan gigi tiruan. Pasien kehilangan gigi 1112 1516172122242526 dan 27 yang diindikasikan untuk pembuatan overdenture gigi tiruan sebagian lepasan (GTS) kerangka logam dengan pegangan telescopic crown pada gigi 13 dan 14 dengan sistem parallel-sided crown.Tahaptahap pembuatan telescopic crown yaitu mencetak model study dengan catatan gigit pendahuluan. Perawatan saluran dilakukan pada akar gigi 13, dilanjutkan pemasangan pasak fiber serta rewalling dinding bukal. Gigi 13 dan 14 dilakukan preparasi mahkota penuh, dilanjutkan dengan pencetakan model kerja untuk coping primer dan kerangka logam dengan metode double impression. Coping primer disementasi pada gigi penyangga, dilanjutkan pasang coba coping sekunder beserta kerangka logam. Selanjutnya dilakukan pencatatan gigit, pencetakan model kerja, penyusunan gigi dan pasang coba penyusunan gigi pada pasien. Prosedur dilanjutkan dengan proses di laboratorium, serta insersi pada pasien. Perawatan GTS kerangka logam dengan kaitan presisi telescopic crown dipilih untuk meningkatkan estetik, retensi gigi, stabilisasi, dan mempertahankan gigi yang masih ada.
\end{abstract}

Maj Ked Gi. Juni 2014; 21(1):72-77

ABSTRACT: Overdenture with Telescopic Crown. Attachment retained overdentures helps in distribution of masticatory forces, minimizes trauma to abutments and soft tissues, attenuate ridge resorption, improves the esthetics and retains proprioception. The purpose of this paper is provide information about the rehabilitation of partially edentulous maxilla patients with telescopic crowns. A 45 years old female came with mastication and aesthetic problems. She had missing teeth as in 11121516172122242526 and 27. In the upper jaw, the remaining tooth 13 and 14, were fabricated as telescopic crowns with parallel-sided system combined with metal framework denture. Fabrication of telescopic crown began by making of study model with preliminary bite record. As in preliminary treatment, root canal treatment was done on 13, proceeded with the cementation of fiber post and rewalling of missing buccal wall. Full crown preparation was done on 13 and 14, and impression was made with double impression technique. Laboratorium procedures for making the primary crowns, secondary crowns and metalwork denture base were finished and the primary crowns were cemented on the abutment teeth. Secondary crowns soldered with metalwork denture base were tried in the patient, bite registration was done, proceeded with impression taking which bite registration embedded inside of the impression. Artificial teeth were arranged and tried to the patient, continued with processing and insertion of the denture. Metal framework removable partial denture with telescopic crown is chosen for this case to improve retention and to preserve the healthy remaining tooth.

Maj Ked Gi. Juni 2014; 21(1):72-77

Kata kunci: overdenture, precision atttachment, telescopic crown

\section{PENDAHULUAN}

Kaitan presisi merupakan pemecahan masalah yang ditimbulkan pada pemakai gigi tiruan, karena dengan menggunakan kaitan presisi akan mencegah kerusakan pada jaringan yang mendukung gigi tiruan dan merupakan perkembangan dari pemakaian oklusal rest pada gigi tiruan sebagian lepasan konvensional. ${ }^{1}$ Kaitan presisi dapat digunakan secara luas pada gigi tiruan cekat, gigi tiruan sebagian lepasan, 
overdenture, implant untuk retensi overdenture, dan protesa maksilo fasial. Kaitan presisi terdiri dari dua bagian atau lebih, satu bagian terhubung dengan akar gigi, gigi, atau implant, dan bagian yang lain terhubung dengan gigi tiruan. ${ }^{2}$

Overdenture adalah gigi tiruan lengkap atau sebagian yang didukung oleh jaringan lunak, dan akar gigi atau implant. Overdenture meningkatkan retensi, stabilitas dan dukungan, meningkatkan efisiensi pengunyahan, menjaga tulang alveolar dan pola otot, serta mempertahankan reseptor sensorik dalam ligamen periodontal. Retensi dan stabilitasi overdenture dapat ditingkatkan dengan menggunakan kaitan presisi atau magnet. ${ }^{3}$

Overdenture telescopic merupakan pengembangan dari overdenture konvensional, dengan keuntungan yang lebih daripada overdenture konvensional. Konsep telescopic crown berasal dari mikroskop optik yang bekerja menggunakan prinsip gerakan antara dua silinder paralel. Telescopic crown adalah gigi tiruan dengan dukungan kombinasi gigi dan mukosa, merupakan protesa lepasan yang didesain pas dengan gigi aslinya dan jaringan lunak di sekitarnya dengan tujuan untuk mengganti gigi yang hilang. ${ }^{4,5}$

Protesa telescopic crown terdiri dari: a. Coping primer atau topi, yang terbuat dari logam mulia atau tidak mulia, yang disemen pada gigi yang telah dipreparasi. b. Coping sekunder (logam campuran) yang dimasukkan ke dalam mahkota sekunder, dengan tujuan untuk mempertahankan gigi melalui mekanisme sliding friksi yang ketat pada gigi. Coping sekunder ini memiliki permukaan facing yang akan di isi dengan resin akrilik, komposit, atau ceramic. c. Kerangka terbuat dari logam campuran tidak mulia yang tertanam dalam resin akrilik untuk menyangga gigi akrilik yang akan berfungsi untuk menggantikan gigi hilang. ${ }^{5}$

Retensi dari telescopic crown dicapai dengan memanfaatkan gaya gesekan, dan coping yang berbentuk conical atau tapered. Besarnya gaya gesek terutama ditentukan oleh sudut konvergensi dari bagian dalam mahkota. ${ }^{6}$ Ada 2 macam sistem dalam gigi tiruan sebagian lepasan dengan telescopic crown, yaitu sistem conical crown, dan sistem parallel-sided crown. Sistem conical crown menggunakan tegangan pegas dari mahkota sekunder bagian luar, yang menutupi mahkota primer di bagian dalam. Kekuatan retensi dapat disesuaikan dari sedang hingga kuat, tergantung pada sudut konvergensi dari mahkota bagian dalam. Sistem parallel-sided crown menggunakan gesekan permukaan yang berlawanan dari mahkota bagian dalam dan mahkota. Gesekan dihasilkan dari elemen friksi yang dipasang pada bagian dalam dari mahkota sekunder. ${ }^{7}$ Pasien telah menyetujui kasusnya untuk dapat dipublikasikan demi kepentingan ilmu pengetahuan dalam naskah ini sebagai laporan kasus, dan sebagai etik untuk riset.

\section{METODE}

Pasien wanita berusia 45 tahun datang ke klinik prostodonsia RSGM Prof.Soedomo dengan keluhan ingin dibuatkan gigi tiruan, karena giginya sudah banyak yang dicabut sehingga mengganggu estetik dan fungsionalnya (Gambar 1). Pasien kehilangan gigi 11121516172122242526 dan 27.

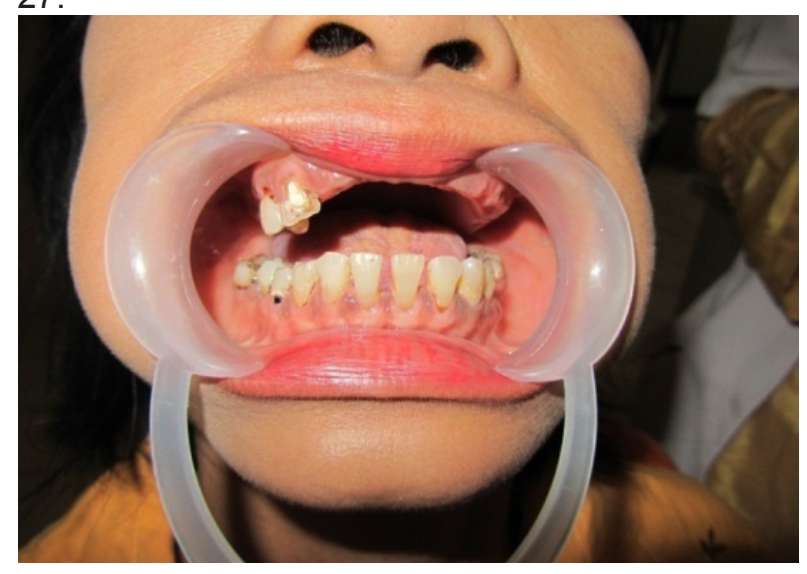

Gambar 1. Gambaran intraoral tampak depan

Kunjungan pertama perawatan adalah membuat studi model dengan sendok cetak stock tray no. 2 dan bahan cetak alginat. Penentuan warna A3 Vita. Pasien dirujuk ke bagian konservasi gigi untuk perawatan saluran akar pada gigi 15 dan 25 (Gambar 2) 


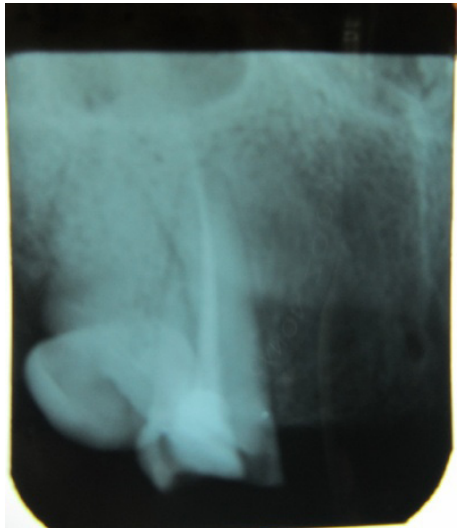

Gambar 2. Foto periapikal gigi 13 setelah perawatan saluran akar

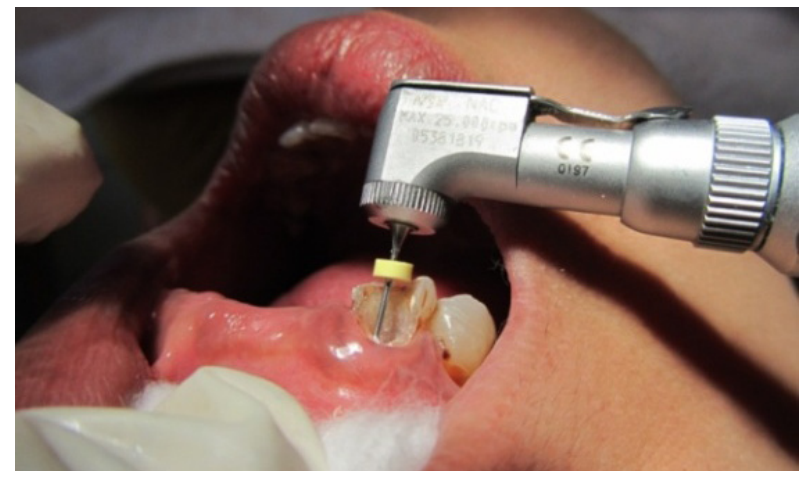

Gambar 3. Pengambilan gutta percha dengan peeso reamer

Pada kunjungan ke-2 setelah perawatan saluran akar selesai, dilakukan pemasangan pasak fiber pada gigi 13. Ambil gutta percha sampai tersisa $1 / 3$ saluran akar dengan peeso reamer (Gambar 3 ), dan lebarkan dinding saluran akar dengan gates glidden drill, kemudian dilakukan pasang coba dan sementasi pasak fiber pada gigi 13 (Gambar 4). Rewalling dinding bukal gigi 13 dengan tumpatan komposit (Gambar 5).

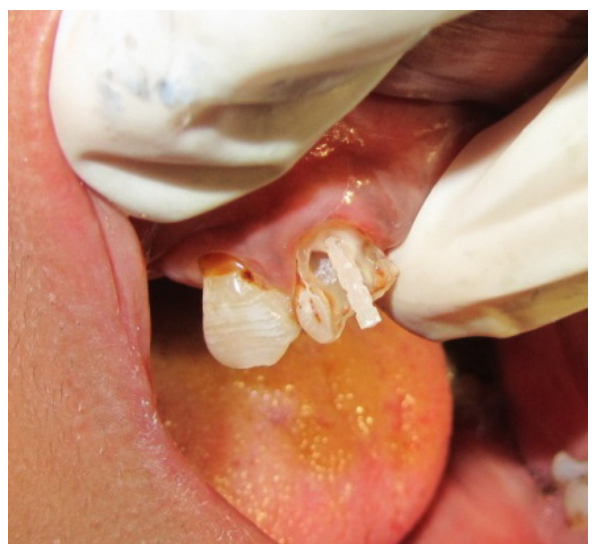

Gambar 4. Pasang coba pasak fiber

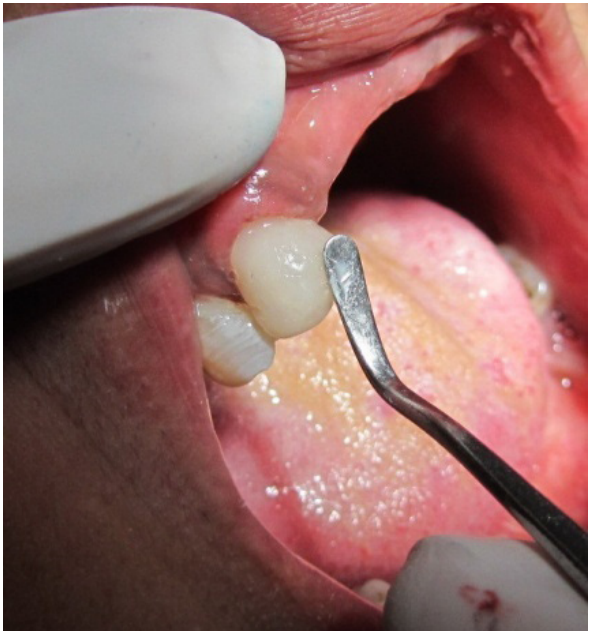

Gambar 5. Rewalling dinding bukal gigi 13

Preparasi mahkota penuh untuk telescopic crown pada gigi 13 dan 14 (Gambar 6). Retraksi gingiva dengan benang dan adrenalin, serta dilakukan pencetakan model kerja dengan sendok cetak perforated stock tray dengan bahan cetak polyvinyl siloxane. Pembuatan mahkota sementara dengan bahan self curing akrilik. Proses laboratoris dilakukan untuk pembuatan double crown.

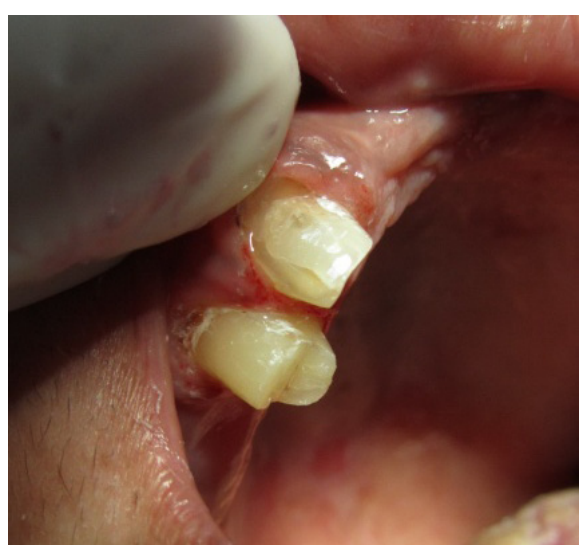

Gambar 6. Hasil preparasi pada gigi 13 dan 14

Pada kunjungan ke-3 setelah framework coping pimer jadi, dilakukan pasang coba pada gigi 13 dan 23 (Gambar 7 dan 8). Cek ketepatan batas tepi dari framework coping primer. Pencetakan dilakukan

Pencetakan dilakukan dengan bahan cetak polyvinyl siloxane beserta framework coping primer (Gambar 9), dan kirim kembali ke laboratorium untuk proses akhir pembuatan coping primer, coping sekunder, dan basis GTS kerangka logam. 


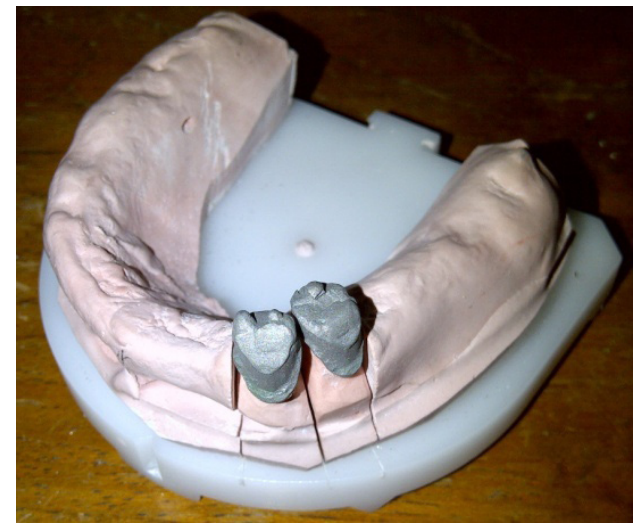

Gambar 7. Framework coping primer

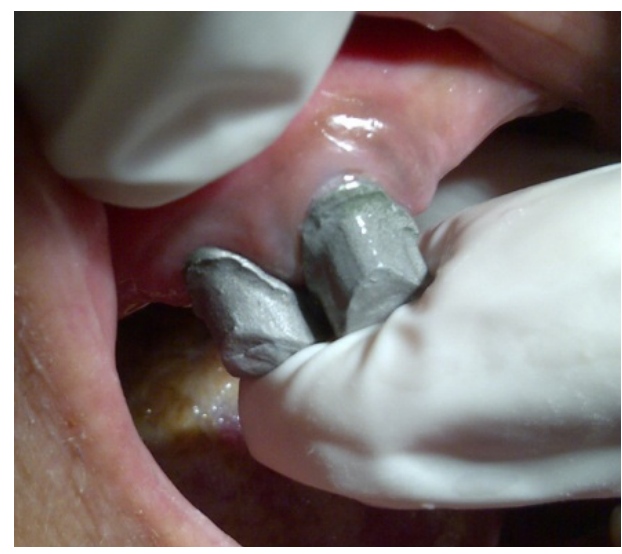

Gambar 8. Pasang coba coping primer

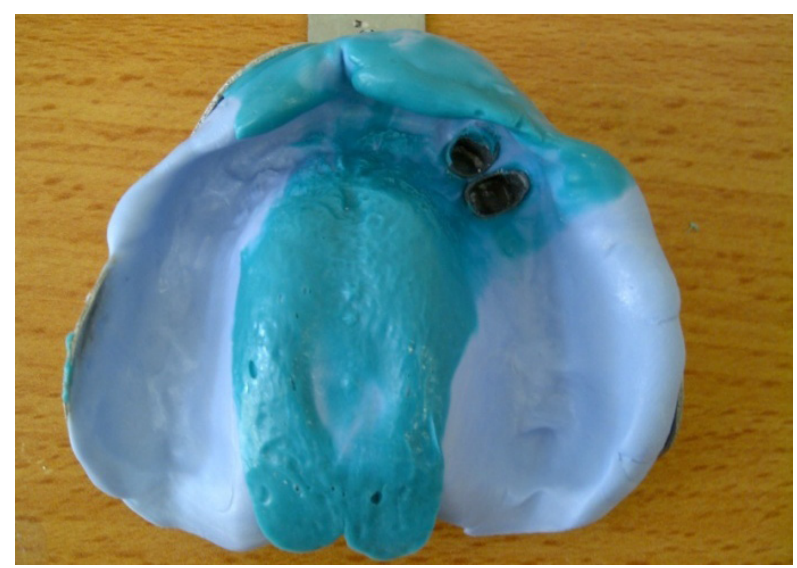

Gambar 9. Coping primer di cetak

Pada kunjungan ke-4 setelah koping primer, coping sekunder dan basis GTS kerangka logam jadi, dilakukan pasang coba coping primer pada gigi 13 dan 14 (Gambar 10 dan 11). Setelah pengepasan, sementasi coping primer dengan luting cement (Gambar 12). Pengukuran tinggi dilakukan gigit/maxillo mandibular relationship. Selanjutnya penanaman dan penyusunan gigi pada artikulator.

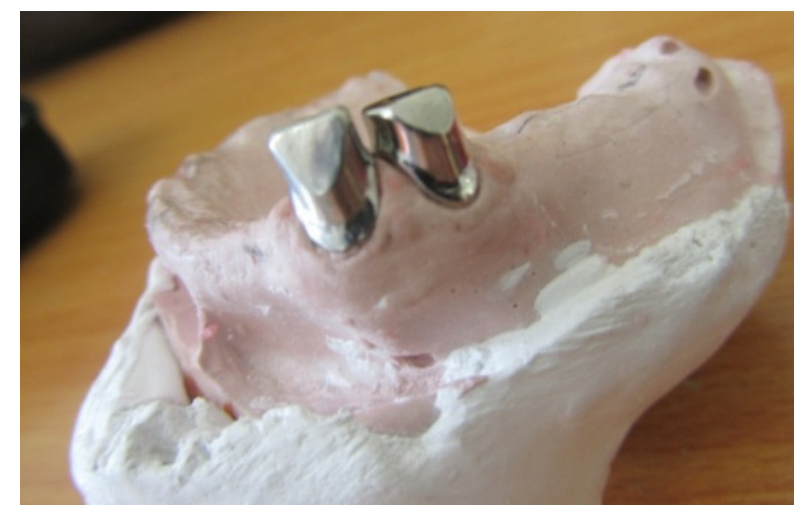

Gambar 10. Coping primer

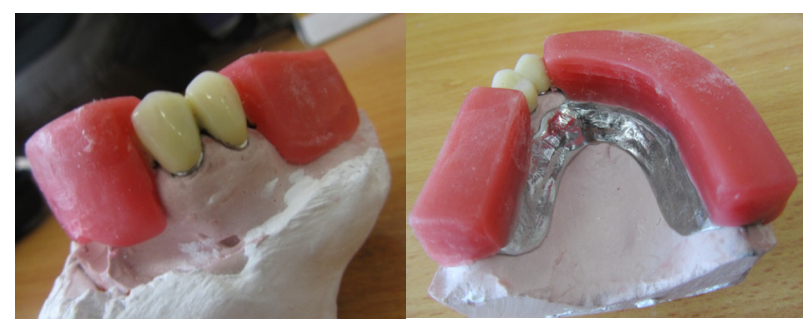

Gambar 11. Coping sekunder beserta basis GTS kerangka logam

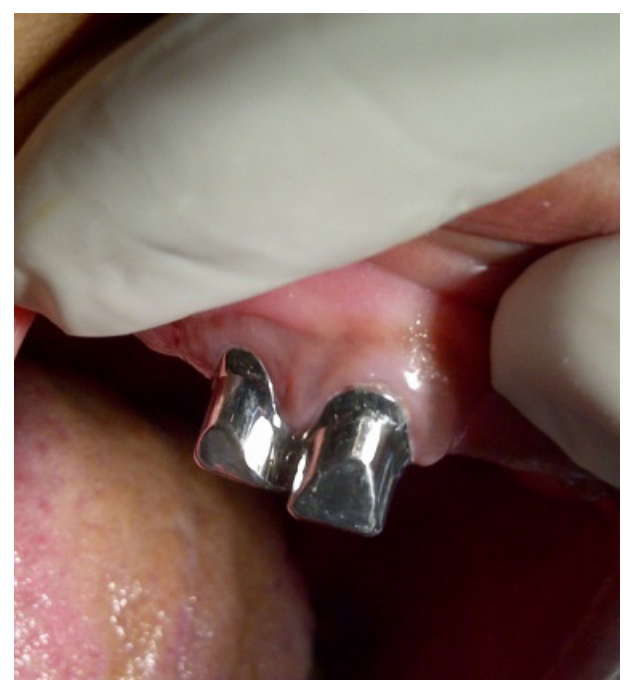

Gambar 12. Penyemenan coping primer

Pada kunjungan ke-5, dilakukan pasang coba penyusunan gigi pada pasien, cek oklusi, retensi, stabilisasi dan estetik. Prosedur dilanjutkan dengan proses laboratoris. 
Pada kunjungan ke-6, pasang coba GTS telescopic crown (Gambar 13). Prosedur dilanjutkan dengan pemasangan friksional element dari BEGO (Gambar 14). Insersi GTS telescopic crown (Gambar 15), cek retensi, stabilisasi, oklusi, estetis dan kenyamanan pasien memakai gigi tiruan. Bila ada traumatik oklusi, dilakukan grinding pada daerah yang mengalami traumatik.

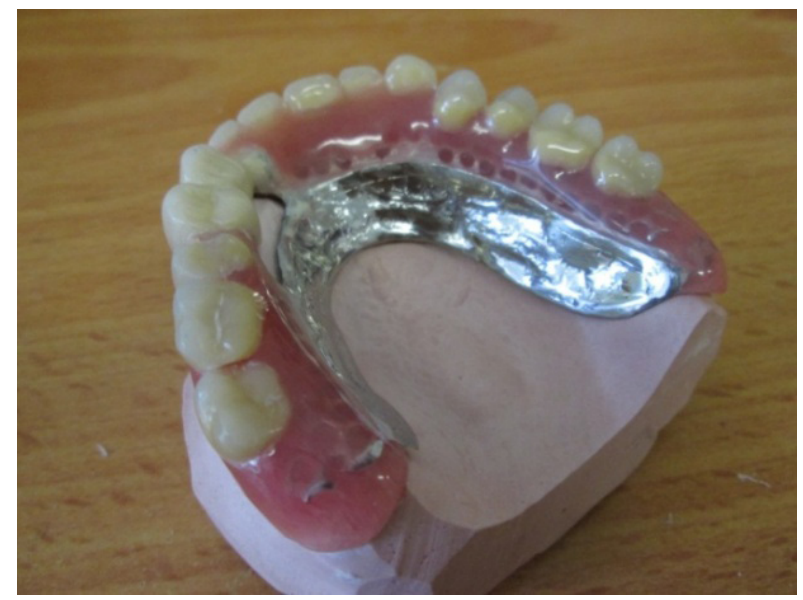

Gambar 13. GTS telescopic crown

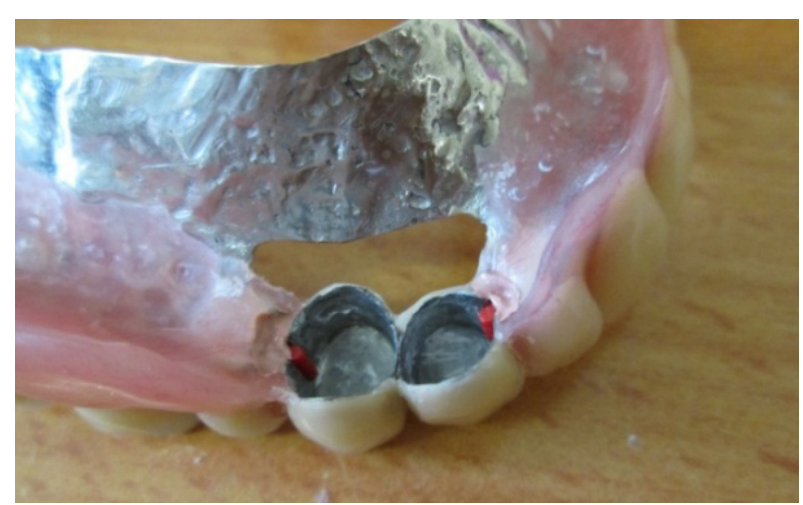

Gambar 14. Pemasangan friksional element dari BEGO

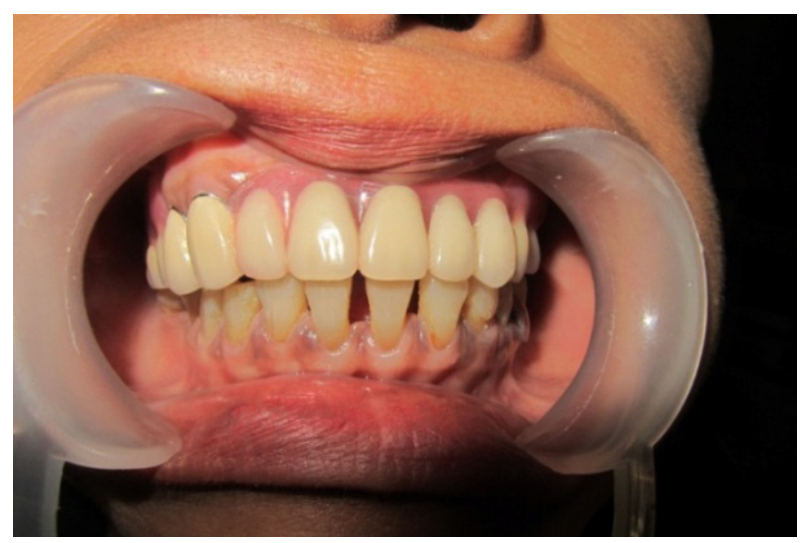

Gambar 15. Insersi GTS telescopic crown
Kontrol dilakukan pada kunjungan ke-7 atau 1 minggu setelah insersi. Pada pemeriksaan subjektif tidak ada keluhan dan pasien merasa puas dengan GTS nya, pada pemeriksaan objektif tidak ada tanda keradangan pada gingiva, tidak terdapat impaksi makanan pada area telescopic crown, retensi, stabilisasi, oklusi baik. Pasien diinstruksikan untuk tetap menjaga kebersihan rongga mulutnya, dan melakukan kontrol periodik untuk dilakukan penggantian friksional elemen apabila sudah aus.

\section{PEMBAHASAN}

Kaitan presisi merupakan pemecahan dalam bidang kedokteran gigi terhadap pasien yang menginginkan estetik dan kenyamanan. ${ }^{2}$ Penggunaan gigi sebagai pegangan overdenture untuk memperlambat dari resorbsi tulang alveolar. Beberapa penelitian menunjukkan pencabutan gigi dan penggunaan gigi tiruan lengkap untuk jangka waktu yang lama menghasilkan resorbsi tulang alveolar. ${ }^{4}$

Pada kasus perawatan GTS dengan kehilangan gigi yang cukup banyak, penggunaan GTS overdenture dengan kaitan presisi telescopic crown dapat menjadi pilihan alternatif. Perawatan GTS overdenture kerangka logam dengan kaitan presisi telescopic crown dipilih untuk mempertahankan gigi yang masih ada dan dapat memberi retensi gigi tiruan yang lebih baik daripada gigi tiruan konvensional. Pada kasus ini menggunakan dukungan kombinasi, yaitu gigi dan mukosa. Telescopic crown dipasang dengan penyangga gigi 13 dan 14, dikombinasikan dengan kerangka logam dan gigi artifisial resin akrilik.

Pada kasus ini digunakan telescopic crown dengan sistem parallel-sided crown dengan elemen friksi. Elemen friksi yang digunakan pada kasus ini adalah BEGO WiroFix dengan diameter $1 \mathrm{~mm}$, yang terbuat dari plastik. Pada telescopic crown dengan sistem parallel-sided crown, gaya gesekan yang terjadi hanya pada elemen friksi, tidak pada seluruh permukaan crown. Keuntungan dari sistem parallel-sided crown adalah elemen friksi mudah di ganti jika sudah aus, tidak perlu mengganti telescopic crown seluruhnya. ${ }^{7}$ Perlu dilakukan 
penggantian elemen friksi setiap 3-4 tahun sekali, agar retensi tetap baik.

Pada kontrol setelah 1 minggu, pasien merasa puas dengan gigi tiruannya, dan dapat mengunyah kembali seperti sediakala. Estetik pada GTS dengan telescopic crown sangat baik, karena tidak menggunakan klamer sebagai pegangan. Retensi dan stabilisasi yang didapatkan juga memuaskan, hal ini sesuai dengan pendapat dari Bibinagar yang menyatakan bahwa penggunaan overdenture dengan pegangan telescopic crown menunjukkan retensi dan stabilisasi yang lebih baik daripada GTS overdenture jenis lainnya. ${ }^{4}$

\section{KESIMPULAN}

Overdenture dengan kaitan presisi telescopic crown merupakan suatu alternatif pemecahan yang memungkinkan dalam pembuatan gigi tiruan lepasan dengan mempertahankan gigi yang masih tersisa dan penambahan kaitan telescopic crown sebagai dukungan untuk meningkatkan estetik, retensi, dan stabilisasi gigi tiruan.

\section{DAFTAR PUSTAKA}

1. Siburian SM. Penggunaan kaitan presisi untuk mendukung retensi gigi tiruan sebagian lepasan. Skripsi Sarjana Universitas Sumatera Utara. 2000; 1-16
2. Makkar S, Chhabra A, Khare A. Attachment retained removable partial denture: a casereport int. J Clin Dent-Sci. Mei 2011; 2(2):39-42.

3. Jayasree K, Bharathi M, Dileep N V, Vinod B. Precision attachment: retained overdenture jindian prosthodont soc. Jan-Mar 2012; 12(1):59-62

4. Bibinagar R, Anam C, Mamidi P, Saxena A, Gautam, Rathinam J. Telescopic overdenture journal of orofacial research, Januari-Maret 2013; 3(1):57-62

5. Heker U, Thomas C. Precision dental prosthetics with highly engineered connections Part2 Dental Prosthetics. April 2010;14-18

6. Singh K, Gupta N. Telescopic denturetreatment modality for minimizing the conventional removable complete denture problems: a case report. Journal of Clinical and Diagnostic Research. Juni 2012; 1-2

7. Behr M, Hofmann E, Rosentritt M, Lang R, Handel G. Technical failure rates of double crown-retained removable partial dentures. Clin Oral Invest. 2000; 4:87-90 